\title{
ANALISIS FAKTOR FAKTOR YANG MEMPENGARUHI HARGA CABAI RAWIT DI PASAR BESUKI (STUDI KASUS DI DESA BESUKI KECAMATAN BESUKI KABUPATEN SITUBONDO)
}

\author{
Zainur Rahmad Himawan1), Puryantoro2*) \\ Fakultas Pertanian, Universitas Abdjurachman Saleh SItubondo \\ *Email Korespondensi : puryantoro@unars.ac.id
}

\begin{abstract}
Abstrak
Petani cabai rawit selalu dihadapkan dengan risiko harga produk. Risiko harga produk diindikasikan oleh volatilitas dari harga. Tujuan penelitian ini adalah : 1) menilai risiko harga produk cabai rawit dan 2) menganalisis faktor-faktor yang mempengaruhi risiko harga produk cabai rawit. Penelitian ini menggunakan data primer dan sekunder mengenai harga dan suplai produk harian cabai rawit periode Januari tahun 2018 sampai Mei 2018. Analisis data dengan menggunakan koefisien variasi serta regresi linier berganda. Hasil penelitian menunjukkan bahwa risiko harga cabai rawit di pasar Besuki cenderung rendah. Faktor-faktor yang mempengaruhi risiko harga cabai rawit periode hari ini yaitu harga periode sehari sebelumnya, pasokan cabai rawit periode hari ini dan sebelumnya.
\end{abstract}

Kata Kunci: Risiko Harga Produk, Cabai Rawit, Pasar Besuki

\begin{abstract}
Chili pepper farmers always face the product price risk. The product price risk was indicated by price volatility. The objectives of this study were: 1) to assess the product price risk in chili pepper farming activities, 2) to analyze the factors that influenced chili pepper product price risk. This research utilized primary and secondary data such as daily price and chili pepper supply (during the period of January 2018 to May 2018). Coefficient variation was used to assess the price risk, while multiple linier regression was used to analyze factors that affected the price risk. The results showed that the price risk of chili peppers in Besuki market tended to be low. The factors that affected the price risk of chili peppers in the current period were the chili pepper price risk of the previous period, vegetable supply in the current period and previous period.
\end{abstract}

Key Words: Product Price Risk, Chili Peppers, Besuki Market.

\section{PENDAHULUAN}

Hortikultura merupakan subsektor pertanian yang memiliki kontribusi penting bagi perekonomian Indonesia. Peningkatan Produk Domestik Bruto (PDB) sub sektor hortikultura meningkat dari Rp 174.454 miliar tahun 2015 menjadi Rp 186.909 miliar pada tahun 2016. Kontribusi terhadap sektor pertanian meningkat 14.73 persen menjadi 14.76 persen. Kontribusi terbesar yaitu tanaman perkebunan sebesar 34.23 persen tahun 2015 dan 33.93 persen pada tahun 2016 (Pusat Data dan Informasi Pertanian 2017).

Pada tahun 2012 komoditas sayuran yang memiliki jumlah produksi terbesar yaitu cabai dengan jumlah total 1.656.524 ton. Pada tahun 2012 hingga tahun 2016 produksi cabai meningkat dan menjadi sayuran dengan jumlah produksi terbesar di Indonesia, dengan tingkat pertumbuhan tiap tahunnya yaitu 4.22 persen pada tahun 2012-2013, 8.61 persen 2013-2014, 2.14 persen 2014-2015 dan 2.43 persen 2015- 
2016 (Pusat Data dan Informasi Pertanian 2017). Konsumsi cabai di Indonesia dari tahun 2014 sampai dengan 2016 terus meningkat. Pertumbuhan produksi cabai di Indonesia mengalami peningkatan setiap tahunnya. Peningkatan tersebut disebabkan adanya peningkatan luas lahan dan produktivitas.

Produksi cabai tahun 2016 yaitu sebesar 1.96 juta ton. Kenaikan produksi dari tahun 2015 yaitu sebesar 46.45 ribu ton (2 persen). Peningkatan produksi ini disebabkan oleh kenaikan produktivitas sebesar 0.05 ton per hektar (0.67 persen) dan peningkatan luas panen sebesar 5.506 ribu hektar (1.76 persen) dibandingkan tahun 2015 (Badan Pusat Statistik 2017). Salah satu jenis cabai yang paling sering dikonsumsi oleh masyarakat yaitu cabai rawit. Produksi cabai rawit terbesar di Pulau Jawa berasal dari Propinsi Jawa Timur, yaitu sebesar 238.820 ton pada tahun 2014, 250. 007 ton pada tahun 2015, dan 260.803 ton pada tahun 2016 (Badan Pusat Statistik 2017).

Berdasarkan data diatas dapat disimpulkan bahwa Propinsi Jawa Timur memiliki jumlah produksi cabai rawit terbesar di pulau Jawa. Salah satu kabupaten yang ada di Jawa Timur yaitu Kabupaten Situbondo. Kabupaten Situbondo menghasilkan produksi cabai rawit sebanyak 103.518 ton dari keseluruhan 260.803 ton di Propinsi Jawa Timur (39.7 persen) (Kabupaten Situbondo Dalam Angka (2017)

Berdasarkan data berita resmi statistik tersebut dapat disimpulkan bahwa komoditas cabai memiliki nilai ekonomi yang tinggi dan sangat potensial. Hal ini disebabkan karena pertumbuhan poduksi, peningkatan luasan dan produktivitas panen cabai meningkat setiap tahun. Selain itu cabai sering menjadi trending topik. Hal ini disebabkan karena melonjaknya harga cabai di pasar.

Setiap bisnis pasti dihadapkan kepada Resiko. Bisnis di bidang pertanian juga memiliki Resiko terutama apabila dilihat dari karakteristik komoditas pertanian yang tergantung pada musim, tidak tahan lama, memakan tempat dan produk tidak seragam. Fluktuasi harga menjadi penyebab terjadinya Resiko harga. Resiko harga tersebut tentunya memiliki faktor-faktor yang mempengaruhinya. fluktuasi harga yang relatif tinggi pada komoditas sayuran pada dasarnya terjadi akibat kegagalan petani dan pedagang sayuran dalam mengatur volume pasokannya sesuai dengan kebutuhan konsumen. Menurut Irawan (2007), Kondisi demikian dapat disebabkan oleh beberapa faktor yaitu :

1. Produksi sayuran cenderung terkonsentrasi di daerah-daerah tertentu saja, misalnya sekitar 90 persen produksi bawang merah nasional hanya dihasilkan di 6 provinsi dan 82 persen produksi cabai dihasilkan di 7 provinsi. Struktur produksi demikian tidak kondusif bagi stabilitas harga karena jika terjadi anomali produksi (misalnya gagal panen akibat hama atau lonjakan produksi akibat pengaruh iklim) di salah satu daerah sentra produksi maka akan berpengaruh besar terhadap keseimbangan pasar secara keseluruhan.

2. Struktur produksi yang terkonsentrasi secara regional diperparah pula oleh pola produksi yang tidak sinkron antar daerah produsen. Setiap daerah produsen sayuran umumnya memiliki pola produksi bulanan yang relatif sama sehingga total produksi sayuran cenderung terkonsentrasi pada bulan-bulan tertentu. Konsentrasi produksi secara temporer tersebut misalnya dapat disimak pada pola produksi kentang dan kubis di Sumatera Utara, Jawa Barat, Jawa Tengah dan Jawa Timur yang menyumbang sekitar 90 persen dan 78 persen produksi nasional. Di keempat provinsi tersebut sekitar 60-65 persen produksi kentang dan kubis hanya dihasilkan 
pada bulan Januari hingga Mei sehingga pada bulan-bulan tersebut harga kedua komoditas tersebut cenderung mengalami penurunan tajam.

3. Permintaan komoditas sayuran umumnya sangat sensitif terhadap perubahan kesegaran produk. Sementara itu komoditas sayuran umumnya relatif cepat busuk sehingga petani dan pedagang tidak mampu menahan penjualannya terlalu lama dalam rangka mengatur volume pasokan yang sesuai dengan kebutuhan pasar, karena hal itu dapat berdampak pada penurunan harga jual yang disebabkan oleh penurunan kesegaran produk. Konsekuensinya adalah pengaturan volume pasokan yang disesuaikan dengan kebutuhan konsumen tidak mudah dilakukan karena setelah dipanen petani cenderung segera menjual hasil panennya agar sayuran yang dipasarkan masih dalam keadaan segar.

4. Untuk dapat mengatur volume pasokan yang sesuai dengan kebutuhan konsumen maka dibutuhkan sarana penyimpanan yang mampu mempertahankan kesegaran produk secara efisien. Namun ketersediaan sarana penyimpanan tersebut umumnya relatif terbatas akibat kebutuhan investasi yang cukup besar sedangkan teknologi penyimpanan sederhana yang dapat diterapkan oleh petani sangat terbatas.

Beberapa daerah memiliki kebijakan tersendiri dalam mengendalikan harga cabai. Akan tetapi kebijakan yang diterapkan masih dalam kerangka menjaga harga cabai tidak jatuh di daerah-daerah sentra produksi terutama pada musim panen raya. Pola tanam dan perencanaan tanam yang tidak terorganisi dengan baik, masalah ketidaklancaran distribusi, juga menjadi salah satu pemicu tingginya lonjakan harga cabai pada saat paceklik karena besarnya gap supply dan demand pada saat panen raya dan paceklik.

Berdasarkan uraian pada latar belakang di atas, maka dirumuskan masalah sebagai berikut:

1.) Berapa nilai Resiko harga cabai rawit di Pasar Besuki?

2.) Faktor-faktor apa saja yang mempengaruhi harga cabai rawit di Pasar Besuki?

\section{METODE PENELITIAN}

Metode penelitian yang digunakan dalam penelitian ini adalah metode kuantitatif. Lokasi penelitian ditentukan secar sengaja (purposive) yaitu di Pasar Besuki dimana fokus lokasi dimana responden akan ditemui dan dilakukan wawancara dengan kuesioner terstruktur yang telah disiapkan. Metode pengambilan contoh yang digunakan adalah metode sampling jenuh. Jumlah populasi yaitu sebanyak 16 orang, maka sampel yang diteliti sebanyak 16 orang. Resiko harga secara tegas berhubungan dengan perubahan dalam setiap periode waktu yang ditunjukkan dengan adanya fluktuasi harga. Resiko dari harga cabai dapat dikukur menggunakan koefisien variasi.

Koefisien variasi adalah perbandingan antara simpangan baku dengan rata-rata suatu data. Koefisien variasi dirumuskan sebagai berikut :

Dimana :

$$
K V=\frac{S}{\bar{x}} x 100 \%
$$

$\mathrm{KV}=$ koefisien variasi

$\bar{x}=$ rata - rata hitung

$\mathrm{S}=$ standar deviasi (simpangan baku) 

Selanjutnya analisis kuantitatif yang dilakukan untuk menganalisis faktor-faktor yang mempengaruhi fluktuasi atau Resiko harga cabai rawit adalah dengan menggunakan Regresi Linier Berganda. Analisis data diolah dengan bantuan program SPSS.

Regresi linier berganda berguna untuk mendapatkan pengaruh dua variabel kriterium atau untuk mencari hubungan fungsional dua prediktor atau lebih dengan variabel kriteriumnya atau untuk meramalkan dua variabel prediktor atau lebih terhadap variabel kriteriumnya. Untuk keperluan analisis, variabel bebas akan dinyatakan dengan $\mathrm{X}$ sedangkan variabel tidak bebas dinyatakan dengan $Y$.

Model regresi linier berganda adalah :

$Y=\alpha+\beta_{1} X_{1}+\beta_{2} X_{2}+\cdots+\beta_{n} X_{n}$

dimana:

Y : Variabel terikat (nilai yang diprediksikan)

$\mathrm{X} \quad$ : Variabel bebas

$\alpha \quad$ : Konstanta

$\beta \quad$ : Koefisien regresi

\section{HASIL DAN PEMBAHASAN}

Penilaian Resiko harga komoditas cabai rawit berdasarkan pada deskripsi statistik yaitu ukuran standar deviasi dan koefisien variasi.

Tabel 1. Deskripsi Statistik Harga Harian Komoditas Cabai Rawit di Pasar Besuki Periode Bulan Januari Sampai Mei 2018

\begin{tabular}{lr}
\hline Deskripsi Statistik & \\
\hline Minimum & Rp. $21.000,00$ \\
Maximum & Rp. $59.000,00$ \\
Mean (Rata-rata) & Rp. $33.586,09$ \\
Standar Deviasi & 9984,114314 \\
Koefisien Variasi & 0,3 \\
\hline
\end{tabular}

Deskripsi statistik mengenai perkembangan harga komoditas cabai rawit selama bulan Januari tahun 2018 sampai Mei 2018 dapat dilihat pada Tabel 1.

Koefisien variasi dapat diketahui dengan menggunakan rumus berikut :

Koefisien variasi $=\frac{\text { Standar deviasi }}{\text { Rata }- \text { rata }} \times 100 \%$

$=\frac{9984,114314}{\mathrm{Rp} 33.586,09} \times 100 \%$

$=0,3$

Rata-rata harga harian cabai rawit pada periode Januari tahun 2018 sampai Mei tahun 2018 sebesar Rp. 33.586,09 /kg. Adapun koefisien variasi pada cabai rawit sebesar 0,3 , yang artinya setiap harga Rp 1.000 yang diharapkan akan diterima pelaku usaha cabai rawit maka Resiko yang dihadapi pelaku usaha sebesar Rp 300. Berdasarkan pada penelitian Salim (2016) yang menyatakan bahwa, apabila nilai koefisien variasi lebih besar dari 0.5 maka, suatu komoditi memiliki nilai Resiko harga yang tinggi. Sebaliknya, apabila nilai koefisien variasi lebih kecil dari 0.5 maka, memiliki nilai Resiko harga yang 
rendah. Hal tersebut menunjukkan bahwa Resiko harga cabai rawit di pasar Besuki cenderung rendah, karena memiliki nilai koefisien variasi sebesar 0,3.

Faktor - faktor yang mempengaruhi harga cabai rawit dianalisis menggunakan regresi linier berganda dengan bantuan program SPSS sebagai berikut :

Tabel 2. Hasil Analisis Regresi Linear Berganda

\begin{tabular}{llrrrrr}
\hline \multirow{2}{*}{ Model } & & \multicolumn{2}{c}{ Unstandardized } & \multicolumn{2}{c}{$\begin{array}{c}\text { Standardized } \\
\text { Coefficients }\end{array}$} & \multicolumn{2}{c}{ Coefficients } & \multirow{2}{*}{ Sig. } \\
\cline { 3 - 5 } & & \multicolumn{1}{c}{$\mathrm{B}$} & \multicolumn{1}{c}{ Std. Error } & Beta & & \\
\hline 1 & (Constant) & 1091,340 & 2354,676 & & 0,463 & 0,647 \\
& Harga Sebelumnya & & & & & \\
& & 0,817 & 0,108 & 0,829 & 7,537 & 0,000 \\
& Pasokan & 2157,582 & 753,293 & 0,323 & 2,864 & 0,008 \\
& Pasokan & & & & & \\
& Sebelumnya & $-1173,643$ & 846,264 & $-0,175$ & $-1,387$ & 0,177 \\
\hline
\end{tabular}

Uji t

1. Pengujian koefisien regresi variabel Harga Sebelumnya(X1)

Nilai sig lebih kecil dari nilai probabilitas 0,05, maka Ha diterima dan Ho ditolak. Variabel Harga cabai rawit periode sehari sebelumnya (Harga Sebelumnya) mempunyai t-hitung yakni 7,537 dengan t-tabel 2,056. Jadi t-hitung > t-tabel dapat disimpulkan bahwa variabel Harga cabai rawit periode sehari sebelumnya (Harga Sebelumnya) memiliki kontribusi terhadap Harga cabai rawit periode hari ini (Harga). Nilai t positif menunjukan bahwa variabel Harga cabai rawit periode sehari sebelumnya (Harga Sebelumnya) mempunyai hubungan searah dengan Harga cabai rawit periode hari ini (Harga). Jadi dapat disimpulkan bahwa Harga cabai rawit periode sehari sebelumnya (Harga Sebelumnya) memiliki pengaruh signifikan terhadap Harga cabai rawit periode hari ini (Harga).

\section{Pengujian koefisien regresi variabel Pasokan(X2)}

Nilai sig lebih kecil dari nilai probabilitas 0,05, maka Ha diterima dan Ho ditolak. Variabel Pasokan cabai rawit periode hari ini (Pasokan) mempunyai t-hitung yakni 2,864 dengan ttabel 2,056. Jadi t-hitung > t-tabel dapat disimpulkan bahwa variabel Pasokan cabai rawit periode hari ini (Pasokan) memiliki kontribusi terhadap Harga cabai rawit periode hari ini (Harga). Nilai t positif menunjukan bahwa variabel Pasokan cabai rawit periode hari ini (Pasokan) mempunyai hubungan searah dengan Harga cabai rawit periode hari ini (Harga). Jadi dapat disimpulkan bahwa Pasokan cabai rawit periode hari ini (Pasokan) memiliki pengaruh signifikan terhadap Harga cabai rawit periode hari ini (Harga).

\section{Pengujian koefisien regresi variabel Pasokan Sebelumnya(X3)}

Nilai sig lebih besar dari nilai probabilitas 0,05, maka Ha ditolak dan Ho diterima. Variabel Pasokan cabai rawit periode sehari sebelumnya (Pasokan Sebelumnya) mempunyai thitung yakni -1,387 dengan t-tabel -2,056. Jadi - t-hitung >- t-tabel dapat disimpulkan bahwa variabel Pasokan cabai rawit periode sehari sebelumnya (Pasokan Sebelumnya) tidak memiliki kontribusi terhadap Harga cabai rawit periode hari ini (Harga). Nilai $t$ negatif menunjukan bahwa variabel Pasokan cabai rawit periode sehari sebelumnya (Pasokan Sebelumnya) mempunyai hubungan yang berlawanan arah dengan Harga cabai rawit periode hari ini (Harga). Jadi dapat disimpulkan bahwa Pasokan cabai rawit periode sehari sebelumnya (Pasokan Sebelumnya) tidak memiliki pengaruh signifikan terhadap Harga cabai rawit periode hari ini (Harga). 
Uji F

Tabel 3. Hasil Uji F

\begin{tabular}{llrrrrl}
\hline Model & & Sum of Squares & df & Mean Square & \multicolumn{1}{c}{ F } & \multicolumn{1}{c}{ Sig. } \\
\hline 1 & Regression & 20784942,50 & 3 & 6928314,167 & 30,583 & 0,000 \\
& Residual & 5890057,499 & 26 & 226540,673 & & \\
& Total & 26675000,000 & 29 & & & \\
\hline
\end{tabular}

Hasil dari tabel 3 dapat dilihat bahwa nilai sig lebih kecil dari nilai probabilitas 0,05, maka Ha diterima dan Ho ditolak. Secara simultan variabel Harga cabai rawit periode sehari sebelumnya (Harga Sebelumnya), Pasokan cabai rawit periode hari ini (Pasokan) dan Pasokan cabai rawit periode sehari sebelumnya (Pasokan Sebelumnya) mempunyai Fhitung yakni 30,583 dengan F-tabel 2,98. Jadi F-hitung > F-tabel dapat disimpulkan bahwa secara simultan variabel Harga cabai rawit periode sehari sebelumnya (Harga Sebelumnya), Pasokan cabai rawit periode hari ini (Pasokan) dan Pasokan cabai rawit periode sehari sebelumnya (Pasokan Sebelumnya) memiliki pengaruh signifikan terhadap Harga cabai rawit periode hari ini (Harga).

\section{Koefisien determinasi $\left(\mathrm{R}^{-2}\right)$}

Tabel 4. Hasil analisis Koefisien determinasi

\begin{tabular}{lcccc}
\hline & & & Adjusted & Std. Error of the \\
Model & $\mathrm{R}$ & R Square & R Square & Estimate \\
\hline 1 & 0,883 & 0,779 & 0,754 & 475,96289 \\
\hline
\end{tabular}

Untuk perhitungan koefisien determinasi, akan menggunakan Adjusted R Square karena, Menurut Santoso (2001) bahwa untuk regresi dengan lebih dari dua variabel bebas lebih baik menggunakan Adjusted R Square sebagai koefisien determinasi. Berdasarkan Tabel 5.5 diperoleh angka Adjusted R2 (Adjusted R Square) sebesar 0,754 atau $(75,4 \%)$. Hal ini menunjukkan bahwa prosentase sumbangan pengaruh variabel independen (Harga Sebelumnya(X1), Pasokan(X2) dan Pasokan Sebelumnya(X3)) terhadap variabel dependen (Harga(Y)) sebesar 75,4\%. Atau variasi variabel independen yang digunakan dalam model (Harga Sebelumnya(X1), Pasokan(X2) dan Pasokan Sebelumnya(X3)) mampu menjelaskan sebesar $75,4 \%$ variasi variabel dependen (Harga(Y)). Sedangkan sisanya sebesar 24,6\% (100\%-75,4\%) dipengaruhi atau dijelaskan oleh variabel lain yang tidak dimasukkan dalam model penelitian ini.

Temuan hasil penelitian ini sejalan dengan hasil penelitian dari Fariyanti, Fausia, dan Lusi (2011) yang menyatakan bahwa, sekitar 94,9 persen keragaman harga cabai merah besar dapat dijelaskan oleh keragaman variabel harga cabai merah besar periode sehari sebelumnya, pasokan cabai merah besar periode sehari sebelumnya dan periode hari ini. Serta, berdasarkan hasil pendugaan menunjukkan bahwa variasi harga cabai merah besar pada periode hari ini dipengaruhi secara nyata oleh harga cabai merah besar pada periode sehari sebelumnya. Meskipun secara simultan Harga Cabai Rawit Periode Sehari Sebelumnya(Harga Sebelumnya), Pasokan Cabai Rawit Periode Hari Ini(Pasokan) dan Pasokan Cabai Rawit Periode Sehari Sebelumnya(Pasokan Sebelumnya) dapat memberikan pengaruh yang signifikan terhadap Harga Cabai Rawit Periode Hari Ini(Harga), namun dalam penelitian ini variabel Pasokan Cabai Rawit Periode Sehari Sebelumnya(Pasokan Sebelumnya) secara parsial tidak dapat memberikan pengaruh terhadap Harga Cabai Rawit Periode Hari Ini(Harga). Nilai koefisien Pasokan cabai rawit periode hari ini (Pasokan) untuk variabel X2 sebesar 2157,582. Artinya jika variabel 
independen lain nilainya tetap dan Pasokan cabai rawit periode hari ini (Pasokan) mengalami kenaikan $1 \mathrm{Kg}$, maka Harga cabai rawit periode hari ini (Harga) akan mengalami peningkatan sebesar Rp.2157,582. Koefisien bernilai positif artinya terjadi hubungan positif antara Pasokan cabai rawit periode hari ini (Pasokan) dengan Harga cabai rawit periode hari ini (Harga), semakin naik Pasokan cabai rawit periode hari ini (Pasokan) maka semakin meningkat Harga cabai rawit periode hari ini (Harga). Hal ini tidak sesuai dengan hukum ekonomi yang menyatakan bahwa semakin banyak jumlah barang yang ditawarkan maka akan semakin turun harganya. Hal ini diduga dipengaruhi oleh permintaan dari konsumen yang juga meningkat, baik itu karena selera, kualitas produk yang meningkat ataupun untuk memenuhi kebutuhan tradisi keluarga atau acara tertentu. Sehingga menyebabkan harga tetap meningkat meskipun pasokan mengalami peningkatan.

\section{KESIMPULAN}

Berdasarkan hasil dari pembahasan sebelumnya, maka dapat ditarik kesimpulan sebagai berikut :

1. Berdasarkan penghitungan analisis Resiko harga yang telah dilakukan pada penelitian ini diketahui bahwa Resiko harga cabai rawit di pasar Besuki termasuk ke dalam kategori Resiko rendah.

2. Faktor-faktor yang mempengaruhi harga cabai rawit periode saat ini dipengaruhi oleh harga cabai rawit satu hari sebelumnya dan pasokan cabai rawit periode hari ini, sedangkan pasokan cabai rawit periode sehari sebelumnya tidak berpengaruh.

\section{REFERENSI}

Badan Pusat Statistik Kabupaten Situbondo, 2017. Kabupaten Situbondo Dalam Angka. Situbondo: Badan Pusat Statistik Kabupaten Situbondo.

Badan Pusat Statistik. 2017. Statistik Pertanian. Jakarta: Badan Pusat Statistik.

Fariyanti, Fausia A., dan Lusi. 2011. Resiko Harga Sayuran di Indonesia. Prosiding Seminar Penelitian Unggulan Departemen Agribisnis. Bogor: Departemen Agribisnis Fakultas Ekonomi dan Manajemen Institut Pertanian Bogor. Halaman 1-22

Irawan, B. 2007. FLUKTUASI HARGA, TRANSMISI HARGA DAN MARJIN PEMASARAN SAYURAN DAN BUAH. Analisis Kebijakan Pertanian. Volume 5 No. 4, Desember 2007: 358-373

Salim, M. A. 2016. Analisis Resiko Harga Cabai di Pasar Induk Kramat Jati [skripsi]. Bogor: Institut Pertanian Bogor.

Santoso, S. 2001. SPSS Versi 10 : Mengolah Data Statistik Secara Profesional. Jakarta : PT Elex Media Komputindo. 